\begin{tabular}{c}
$\begin{array}{c}\text { Jom Jurnal Rekam Medis (Medical Record Journal) } \\
\text { e-ISSN } 2776-6314\end{array}$ \\
https://jom.htp.ac.id/index.php/rmik \\
\hline
\end{tabular}

\title{
Tinjauan Aspek Keamanan dan Kerahasiaan Rekam Medis di Ruang Filling Rumah Sakit Umum Daerah Petala Bumi Tahun 2021
}

\author{
Sri Nurmariza ${ }^{1}$, Ulil Kholili $^{2}$, Ahmad Hanafi $^{3}$ \\ ${ }^{1,2}$ Program Studi DIII Rekam Medis Dan Informasi Kesehatan \\ Sekolah Tinggi IImu Kesehatan Hang Tuah Pekanbaru \\ Email: 'snurmariza@gmail.com, 20ulilkholili2017@gmail.com, 3ah0540705@gmail.com
}

\begin{tabular}{l} 
Histori artikel \\
\hline Received: \\
15 Juli 2021 \\
Accepted: \\
19 September 2021 \\
Published: \\
26 Oktober 2021
\end{tabular}

\begin{abstract}
Abstrak
Keamanan dokumen rekam medis menyangkut dalam bahaya dan kerusakan dokumen rekam medis, berdasarkan observasi awal pada ruang filling terdapat kekurangan dari aspek fisik, kimiawi maupun biologis. Tujuan dari penelitian ini untuk mengetahui tentang keamanan dan kerahasiaan rekam medis di ruang filling. Metode penelitian yang digunakan adalah penelitian kualitatif, lokasi dan waktu penelitian di Rumah Sakit Umum Daerah Petala Bumi pada bulan Desember 2020 s/d april 2021. Dengan informan berjumlah 3 orang. Instrumen yang digunakan adalah wawancara, observasi, dokumentasi dan alat perekam. Teknik pengolahan data dengan menggunakan teknik non statistik, analisa data menggunakan triangulasi. Hasil penelitian berdasarkan aspek fisik menggunakan kertas HVS A4, tinta berwarna hitam, masih banyak berkas rekam medis yang tidak diletakkan dirak penyimpanan.Aspek biologis bahwa adanya penyemprotan setiap bulan untuk melindungi rekam medis dari serangan serangga dan belum ada rekam medis yang rusak akibat serangga. Aspek kimiawi bahwa masih ada petugas yang membawa makanan atau minuman didekat rekam medis. SDM bahwa petugas rekam medis di ruang filling masih kurang. Memiliki Standar Operasional Prosedur (SOP). Pada sarana dan prasarana diruang filling yaitu luas ruangan penyimpanan berkas rekam medis belum memadai dan kekurangan rak penyimpanan karena ruangannya kecil dan pas-pasan. Penelitian disimpulkan bahwa keamanan rekam medis berdasarkan aspek fisik, biologis, kimiawi belum dikatakan maksimal karena masih banyak berkas rekam medis aktif yang tidak diletakkan di rak penyimpanan yang bisa merusak rekam medis dan dari aspek kerahasiaan belum sesuai teori karena masih ada petugas lain yang masuk ke ruang penyimpanan rekam medis. Kuantitas SDM kurang dan kualitas SDM cukup baik. SOP sudah diterapkan, Sarana dan prasarana masih kurang. Disarankan agar tidak meletakkan rekam medis disembarang tempat, meningkatkan kualitas dan kuantitas SDM serta mengoptimalkan sarana dan prasarana.
\end{abstract}

Kata Kunci: Rumah Sakit, Keamanan, Kerahasiaan, Rekam Medis 


\section{Latar Belakang}

Rekam Medis adalah berkas yang berisikan catatan dan dokumen tentang identitas pasien, pemeriksaan, pengobatan, tindakan dan pelayanan lain kepada pasien pada sarana pelayanan kesehatan (Depkes RI, 2006). Menurut Permenkes RI No 269/Menkes/Per/III/2008 tentang rekam medis, menjelaskan bahwa rekam medis adalah berkas yang berisikan catatan dan dokumen tentang identitas pasien, pemeriksaan, pengobatan, tindakan dan pelayanan lain yang telah diberikan kepada pasien (Rustiyanto, 2009).

Sistem filling adalah salah satu bagian dalam unit rekam medis yang berfungsi menyimpan dokumen rekam medis, penyediaan dokumen rekam medis untuk berbagai keperluan, perlindungan arsip-arsip dokumen rekam medis terhadap bahaya rusak fisik, kimiawi, dan biologi. Sedangkan Permenkes No. 269/MENKES/2008 pasal 12 ayat 1 bahwa rekam medis memiliki sarana pelayanan kesehatan, ayat 2 bahwa isi rekam medis merupakan milik pasien, maka rumah sakit berkewajiban untuk menjaga kerahasiaan isi dokumen rekam medis dan memelihara keawetannya (Sunny, 2008).

Keamanan dokumen rekam medis menyangkut dalam bahaya dan kerusakan dokumen rekam medis sendiri. Adapun aspek dari kerusakan yang di maksud meliputi aspek fisik, aspek kimiawi, aspek biologis serta pencurian. Aspek fisik adalah kerusakan dokumen seperti kualitas kertas dan tinta yang disebabkan oleh sinar matahari, hujan, banjir, panas dan kelembaban. Aspek kimiawi adalah kerusakan dokumen yang disebabkan oleh makanan, minuman, dan bahan-bahan kimia. Aspek biologis adalah kerusakan dokumen yang disebabkan oleh tikus, kecoa dan rayap. Sedangkan untuk keamanan isi dari dokumen rekam medis perlu adanya ketentuan peminjaman, dalam peminjaman dokumen rekam medis sehingga dapat diketahui keberadaan dokumen dan siapa peminjamnya, dan juga perlu diketahui juga kepentingan peminjaman dokumen dan harus diperhatikan dari aspek hukumnya (Wijiastuti, 2014).

Selain itu untuk menjaga keamanan isi dari dokumen perlu adanya tempat alat yang digunakan untuk menaruh, meletakkan, menyimpan arsip harus aman dan menjaga informasi yang terkandung didalamnya, serta terhadap pencurian oleh orang yang tidak bertanggung jawab dan pengawetan arsip. Sehubung dengan dokumen rekam medis berisi data individual yang bersifat rahasia, maka setiap lembar formulir dokumen rekam medis harus di lindungi dengan cara dimasukkan kedalam folder atau map sehingga setiap folder berisi data dan informasi yang diperoleh dari pasien secara individu (Wijiastuti, 2014).

Pelayanan yang diberikan kepada masyarakat termasuk Rawat Jalan, Rawat Inap, dan IGD 24 jam. Untuk ruang penyimpanan rekam medis di Rumah Sakit Umum Daerah Petala Bumi memiliki 2 (dua) ruang penyimpanan, dengan menggunakan sistem penyimpanan sentralisasi yaitu penyimpanan rekam medis dalam satu berkas baik catatan 
rawat inap, rawat jalan, maupun gawat darurat dan sistem penjajaran berkas rekam medis menggunakan sistem angka akhir (Terminal Digit Filling System). Berdasarkan observasi awal di ruang penyimpanan rekam medis di RSUD Petala Bumi sudah memiliki ruang penyimpanan khusus. Hal ini dapat dilihat pada gambar berikut :

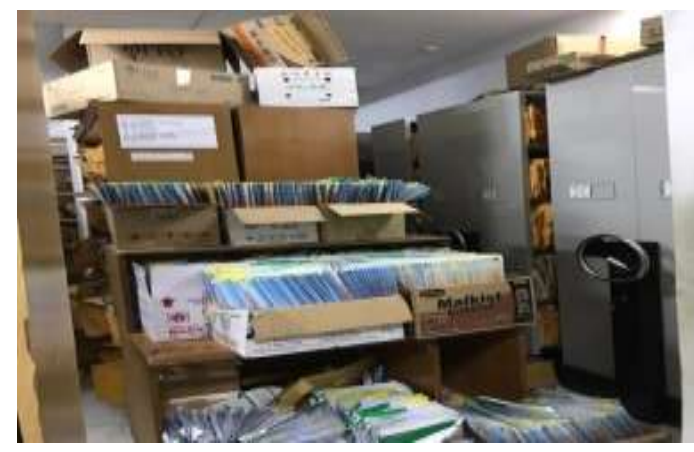

\section{Gambar 1. Ruang Penyimpanan Rekam Medis}

Masih ditemukan beberapa masalah yang berkaitan dengan keamanan dan kerahasiaan rekam medis pasien.Berdasarkan gambar diatasdapat dilihat bahwa dari aspek keamanannya terdapat kekuranganbaik dari aspek fisik, kimiawi maupun biologis. Dari aspek fisikRSUD Petala Bumi yaitu kertas yang digunakan sudah sesuai teori yaitu kertas HVS standar A4, tinta standar berwarna hitam, memiliki rak penyimpanan khusus rekam medis, tetapi masih kekurangan rak penyimpanan sehingga masih terdapat rekam medis aktif yang kurang rapi,banyak rekam medis aktif yang tidak diletakkan di rak penyimpanan karena ruangan rekam medis yang kecil, rekam medis aktif yang berada didasar lantai, ruangan sudah memiliki AC, sudah memiliki alat pemadam api ringan (APAR). Dari aspek biologis sudah dilakukan penyemprotan setiap bulan untuk melindungi rekam medis dari serangan serangga dan tidak ada rekam medis yang rusak akibat serangga, tikus atau pun kecoa, dan dari aspek kimiawi masih terdapat petugas membawa makanan pada saat berada dekat dengan rekam medis. Dari aspek kerahasiaan sudah ada ketentuan peminjaman rekam medis,pada ruang penyimpanan rekam medis pintu sudah menggunakan fingerprint, sudahada peraturan yang dibuat agar selain petugas rekam medisdilarang masuk,belum ada peraturanyang menyatakan bahwa rekam medis bersifat rahasia.

\section{Metode}

Jenis penelitian deskriptif dengan pendekatan metode kualitatif yang menggambarkan tentang bagaimana Pelaksanaan Aspek Keamanan dan Kerahasiaan Rekam Medis di Ruang Filling Rumah Sakit Umum Daerah Petala Bumi Tahun 2021.Penelitian dilakukan di ruang Filling Rekam Medis Rumah Sakit Petala Bumi.Waktu penelitian ini dilaksanakan pada bulan Desember 2020 s/d April 2021 di Rumah Sakit Umum Daerah Petala Bumi.Dari pengumpulan dan Pengambilan Data menggunakan pedoman Jurnal Rekam Medis ( Medical Record Journal) 
Wawancara. Untuk mendukung metode tersebut, maka instrumen yang digunakan sebagaiberikut: Pedoman Wawancara, Pedoman Observasi, Dokumentasi, dan Alat Perekam/Handphone. Menggunakan Triangulasi Sumber, Triangulasi Metode, dan Triangulasi Data.

\section{Hasil}

\section{Hasil Penelitian}

\section{a. Hasil Observasi}

Dari hasil observasi yang dilakukan peneliti terhadap aspek keamanan rekam medis berdasarkan aspek fisik, aspek kimiawi, aspek biologis di Ruang Filling RSUD Petala Bumi bisa dilihat pada tabel berikut:

Tabel 1. Hasil Observasi

\begin{tabular}{|c|c|c|c|c|}
\hline No & Variabel & Ada & $\begin{array}{l}\text { Tidak } \\
\text { Ada }\end{array}$ & Keterangan \\
\hline \multirow[t]{10}{*}{1} & \multicolumn{4}{|l|}{ Aspek fisik } \\
\hline & - Kertas standar A4 & $\sqrt{ }$ & & \multirow{2}{*}{$\begin{array}{lc}\text { Semua } & \text { berkas } \\
\text { menggunakan HVS A4 } \\
\text { Disemua } & \text { ruang } \\
\text { nenvimnanan }\end{array}$} \\
\hline & - $\quad$ AC hidup 24 jam & $\sqrt{ }$ & & \\
\hline & - Atap bocor & & $\sqrt{ }$ & \multirow{2}{*}{$\begin{array}{l}\text { Sudah diperbaiki } \\
\text { Disemua ruang } \\
\text { penyimpanan RM }\end{array}$} \\
\hline & $\begin{array}{l}\text { - APAR (Alat Pemadam } \\
\text { Api Ringan) }\end{array}$ & $\sqrt{ }$ & & \\
\hline & - Tracer & & $\sqrt{ }$ & \multirow{2}{*}{$\begin{array}{l}\text { Tidak } \text { menggunakan } \\
\text { tracer } \\
\text { Ada } 6 \text { buah, masih } \\
\text { kurang }\end{array}$} \\
\hline & - Roll O’Pack & $\sqrt{ }$ & & \\
\hline & - Rak terbuka & $\sqrt{ }$ & & \multirow{2}{*}{$\begin{array}{l}\text { Ada } 6 \text { buah masih } \\
\text { kurang } \\
\text { Tidak ada }\end{array}$} \\
\hline & $\begin{array}{l}\text { - Sinar matahari yang } \\
\text { jatuh dipermukaan } \\
\text { rekam medis }\end{array}$ & & $\sqrt{ }$ & \\
\hline & $\begin{array}{ll}\text { - } & \text { Rekam medis } \\
\text { tercecer }\end{array}$ & $\sqrt{ }$ & & $\begin{array}{l}\text { Ada karena sebagian } \\
\text { RM diletakkan dikotak }\end{array}$ \\
\hline \multirow[t]{3}{*}{2} & Aspek Biologis & & & \\
\hline & - Jamur & & $\sqrt{ }$ & \multirow{2}{*}{$\begin{array}{l}\text { Tidak ada } \\
\text { Tidak ada }\end{array}$} \\
\hline & $\begin{array}{l}\text { - Serangga (Rayap, } \\
\text { kecoa, dan tikus) }\end{array}$ & & $\sqrt{ }$ & \\
\hline \multirow[t]{3}{*}{3} & \multicolumn{4}{|l|}{ Aspek Kimiawi } \\
\hline & $\begin{array}{l}\text { Kerusakan rekam } \\
\text { medis akibat tinta }\end{array}$ & & $\sqrt{ }$ & Tidak ada \\
\hline & $\begin{array}{l}\text { - Makanan/minuman } \\
\text { yang terkena rekam } \\
\text { medis }\end{array}$ & $\sqrt{ }$ & & Pernah ada \\
\hline
\end{tabular}


Dari hasil observasi yang dilakukan peneliti terhadap kerahasiaan rekam medis di RSUD Petala Bumi bisa dilihat dari tabel berikut:

Tabel 2. Hasil Observasi

Variabel

Ada

Tidak Ada

Selain petugas rekam medis yang masuk ke ruang penyimpanan

Rekam medis yang dibawa pasien atau

hilang

Dokter dan perawat wajib menjaga isi rekam

medis

Berdasarkan tabeldiatas dapat disimpulkan bahwa keamanan berkas rekam medis berdasarkan aspek fisik yaitu kertas yang digunakan sudah sesuai dengan teori yaitu kertas standar A4, AC hidup 24 jam, atap tidak ada yang bocor, semua ruangan filling tersedia APAR (alat pemadam api ringan), belum menggunakan tracer untuk mengontrol penggunaan rekam medis setiap kali keluar dari rak penyimpanan, memiliki 2 (dua) jenis rak penyimpanan yaitu rak terbuka dan Roll O'Pack, masih ada rekam medis yang tercecer dilantai. Berdasarkan aspek biologis tidak ada jamur dan serangga dan dari aspek kimiawi masih ada rekam medis yang terkena makanan atau minuman. Dari kerahasiaan masih ada selain petugas rekam medis yang masuk keruangan penyimpanan.

\section{b. Karakteristik Informan}

Tabel 3. Informan Penelitian

\begin{tabular}{lcclc}
\hline $\begin{array}{c}\text { Kode } \\
\text { Informan }\end{array}$ & Jabatan & $\begin{array}{c}\text { Pendidikan } \\
\text { Terakhir }\end{array}$ & $\begin{array}{c}\text { Jenis } \\
\text { kelamin }\end{array}$ & Masa Kerja \\
\hline Informan 1 & $\begin{array}{c}\text { Kepala } \\
\text { Instalasi } \\
\text { Rekam Medis } \\
\text { di RSUD } \\
\text { Petala Bumi }\end{array}$ & $\begin{array}{c}\text { DIII Rekam } \\
\text { Medis, } \\
\text { S1 } \\
\text { Kesehatan } \\
\text { Masyarakat }\end{array}$ & Perempuan & 12 Tahun \\
\hline Informan 2 & $\begin{array}{c}\text { Petugas } \\
\text { rekam medis } \\
\text { di bagian } \\
\text { filling di RSUD } \\
\text { Petala Bumi }\end{array}$ & $\begin{array}{c}\text { DIII Rekam } \\
\text { Medis }\end{array}$ & Laki-laki & 10 Tahun \\
\hline $\begin{array}{c}\text { Petugas } \\
\text { rekam medis } \\
\text { di bagian } \\
\text { filling di RSUD } \\
\text { Petala Bumi }\end{array}$ & S1 Ekonomi & Laki-laki & 4 Tahun \\
\hline Sumber: Rumah Sakit Umum Daerah Petala Bumi & \\
\hline
\end{tabular}

Sumber: Rumah Sakit Umum Daerah Petala Bumi 


\section{c. Hasil Wawancara}

\section{1) Keamanan Rekam Medis Berdasarkam Aspek Fisik}

Dari aspek fisik bahwa untuk masuk kedalam ruang penyimpanan sudah ada access door sehingga rekam medis menjadi lebih aman tetapi masih banyak rekam medis yang di simpan di dalam kotak karena kekurangan lemari penyimpanan rekam medis, dalam pengambilanrekam medis belum ada menggunakan tracer mengakibatkan rekam medis lama ditemukan.

"Untuk aspek fisik, kalo sekarang karena sudah ada access door saya pikir sudah aman, tidak semua orang bisa masuk ke dalam ruang rekam medis kecuali sudah diperbolehkan" (informan 1).

“Kalo untuk sekarang ya keadaannya... fisiknya tidak terpenuhi baik dari segi biologis, fisik, kimia, kenapaaa... roll o'pack nya tidak cukup habis tu tidak semua file tersimpan di roll o'pack masih banyak rak terbuka bahkan masih kardus,terus adalah berkas tercecer karna kan masih ada berkas-berkas diletakkan dikardus tidak menggunakan tracer juga, habis tu yang bahayanya biasanya kalau apaa.. kadang-kadang ada bocoran AC, itu adakan AC diatas rak, bocor AC tu kenak file, itu aja kadang-kadang gangguannya, atau pun dilantai dua itu ada wc bocor wc tu, kadang-kadang kenak file" (informan 2).

Dalam menjaga kemanaan rekam medis dari aspek fisik dengan cara memperhatikan map rekam medis, jika ada yang rusak, map yang rusak tersebut diganti dengan yang baru.

"Map rekam medis yang sudah koyak diganti dengan yang baru biar dia tetap terjaga isi didalamnya"(informan 1).

"Kalo kertas misalnya koyak kan, nantik kalo masih bisa diperbaiki ya diperbaiki kalo gak bisa diganti map yang baru" (informan 3).

\section{2) Keamanan Rekam Medis Berdasarkan Aspek Biologis}

Dari aspek biologis bahwa adanya penyemprotan setiap bulan untuk melindungi rekam medis dari serangan serangga.

"Seranggaaaa selama ini gak ada sih nampak serangga,kecoa gak ada, tikus gak ada karena sudah ada penyemprotan setiap bulan" (informan 1).

"Ada setiap bulan sekali disemprot nii, dikasih cairan-cairan apa gitu biar gak ada binatang, tapi sampai saat ini gak ada binatang didalam gudang ni gak ada binatang, misal rayap, atau tikus gak ada, kecoa gak ada, tapi ada tu tadi berkas-berkas yang terkena percikan dari wc bocor atau ac gitu kadang-kadang belumut dia, tapi kalau bisa diganti kami ganti, biasanya map nya aja tu kami ganti" (informan 2). 
“Kayaknya gak ada nampak berkas rusak akibat rayap gituu, untuk sekarang sih aman-aman ajaa karena ada penyemprotan gitu disini setiap bulan" (informan 3).

\section{3) Keamanan Rekam Medis Berdasarkan Aspek Kimiawi}

Dari aspek kimiawi bahwa tidak ada petugas yang membawa makanan ke dalam ruangan penyimpanan rekam medis, usaha yang digunakan untuk menjaga rekam medis yaitu dengan mengecek kembali rekam medis tersebut.

"Di sana gak ada yang bawa makanan" (informan 1.)

“Untuk aspek kimiaa.. jarang petugas membawa makanan sebabkan disitu gudang, siapa yang mau makan di gudang, orang ni makan ada dimejanya, tapikan file ini kan panjang prosesnyakan sebelum disimpannya tu misalnya gini file yang dari poli tu dikumpulkan dulu dimeja terkadang orang tu makan disitu tumpah mungkin adatapi kalau misal rusak langsung diperbaiki atau pun biar aja kering gitu, misalnya juga gini kan setelah berkas kembali kan misal dari rawat inap di cek di assembling jadi kalau pas rusak di situlah di perbaiki"(informan 2).

\section{4) Kerahasiaan Rekam Medis}

Sebelum masuk ke ruang penyimpanan rekam medis sudah ada acces door, untuk peminjaman berkas sudah ada buku ekspedisi dan di larang masuk sembarangan orang agar terhindar dari pencurian.

“Kalo sekarang karena sudah ada access door saya pikir sudah aman, tidak semua orang bisa masuk ke dalam ruang rekam medis kecuali sudah diperboleh, kalau disini kalau meminjam ada bukti peminjaman terus sudah ada juga peraturan yang ditempel tu didepan selain petugas dilarang masuk"(informan 1).

"untuk keamanan disini sudah sesuai teori karena buktinya aja untuk masuk keruang penyimpanan tidak sembarangan orang bisa masuk, sudah ada access door, kalau orang mau minjam file dicatat semuanya, ada catatannya, gak sembarangan, tapi adakalanya ada juga selain petugas rekam medis yang masuk, kalau perawat-perawat ni mau berobat atau mau cepat dia, dia masuk juga“ (informan 2).

Dalam menjaga kerahasiaan isi rekam medis di RSUD Petala Bumi yaitu orang yang tidak berkepentingan dilarang membawa dan melihat rekam medis seperti yang diungkapkan informan berikut:

"Salah satunya orang yang tidak berkepentingan tidak boleh mengambil atau membawa rekam medis dan melihat rekam medis, jika ada yang ketahuan bahwa rekam medis itu difoto ya nanti dia yang kenak, bisa dituntut, kalau misalnya disini dilarang memfotonya apalagi difotocopy, kalau misal diluar kami 
gak tau yang dirawatan gak tau juga kami tu, tidak mungkin kami setiap hari lihat, tapi kalau didalam sini gak ada" (informan 1).

“kalau misalnya pasien itu mau melihat, dimintaknya, kami fotocopykan, kalau misalnya orang yang gak dikenal ya gak dikasi lah, ada keperluan apa dia meminjam, status tu dimintak biasanya ada keperluan asuransi, misal pasiennya meninggal dia butuh asuransi ha ituu dia dipinjam-pinjam, kalau pihak luar gak ada yang minjam" (informan 2).

"misalnya ada orang yang minjam itu harus ada izin dari petugas atau dari karunya, kami kan tugasnya untuk menjaga file itu, kalau isinya kurang paham, gak mungkin bukak-bukak semuanya kan, paling yang tau isinya dokter, perawat, koding, tapi bagian filling ya paling keamanan dari file itu aja, basicnya kurang paham, kami hanya menjaga dalam segi fisik file itu aja, bahwa file itu ada ditempat gituu.."(informan 3).

\section{5) Kuantitas dan Kualitas Sumber Daya Manusia}

Jumlah tenaga Sumber Daya Manusia yang ada di instalasi rekam medis khususnya di ruang filling masih kurang yaituberjumlah 2 orang.

"ketersediaan sumber daya manusianya masih kurang"(informan 1).

"kami sekarang sudah tercukupi lah karna ada 3 orang yang aktif jadi tercukupi"(informan 2).

"ketersediaannya ya kami cukup lah, kalau lebih enggak tapi cukup gitu"(informan 3).

Dan kualitas sumber daya rekam medis sudah cukup bagus walaupun tidak semuanya berlatar belakang rekam medis, seperti yang di ungkapkan informan berikut:

"kalau kemampuan stafnya sudah cukup bagus walaupun tidak semuanya berlatar belakang petugas rekam medis tapi kalau sudah diajarkan sudah tau"(informan 1).

"kemampuan stafnya alhamdulillah sudah juga, sudah tercukupi "(informan 2).

“kemampuan stafnya pun saya rasa cukup"(informan 3).

\section{6) Ketersediaan Standart Operasional Procedure (SOP)}

Sudah memiliki Standart Operasional Procedur (SOP)

“iya disini sudah ada SOP untuk penyimpanan rekam medis"(informan 1).

Untuk penerapan SOP di rekam medis sudah diterapkan juga oleh tenaga kerja yang ada di rekam medis seperti yang di ungkapkan informan berikut: 
"alhamdulillah sudah, kadang ada juga sih yang ngeyel-ngeyel" (informan 1).

"SOP nya sudah ada dan kayaknya kami sudah jalan keras semuanya, makanya lancar-lancar aja kan dan insyaallah sudah diterapkan dengan baik" (informan 2).

"sudah diikuti.. ya prosedurnya tetap diikuti dengan baik" (informan 3).

\section{7) Ketersediaan Sarana dan Prasarana}

Untuk sarana dan prasarana dibagian rekam medis khususnya dibagian filling belum mencukupi, rak penyimpanan rekam medis masih banyak yang kurang, serta ruangannya yang kecil.

"Belumm, contohnya ee... raknya masih kurang, ruangan nya juga terlalu kecil" (informan 1).

“Belumm mencukupi, Roll O'Pack nya kurang makanya banyak yang di kardus karna ruangan kami ni gak cukup lagi, mau masukkan Roll O’Pack gak cukup karena ruangan ni kurang besar makanya pakai kardus sekarang, itu aja masalahnya, nanti kalau ruangannya sudah di tambah di perbesar ha mungkin bisa masuk Roll O'Pack lagi, tersimpan rapi semua filenya, sekarang belum rapi"(informan 2).

"Sarana dan prasarana nya ya itu tadi dia.. kekurangan tempat, ruangannya kurang memadai, kecil, kita bantu dengan karton karna pasiennyakan banyak setiap hari tu minimal dia 30 sampai 50 pasien, ruangan tu gitu-gitu aja tidak ditambah, raknya kurang lemarinya kurang karena gedung kami ni kan agak sulit memperbesarnya, mungkin kalau mau di naikkan kelantai atas butuh proses pulak harus ada anggaran dari pihak kantor jadi gak semudah itu memperbesar, jadi ruangan ini aja yang bisa kita perbaiki tapi kalau untuk terbaiknya yahhh... kita memperbesar rumah sakitnya"(informan 3).

\section{Pembahasan}

\section{Keamanan Rekam Medis Berdasarkam Aspek Fisik}

Aspek fisik yang dinilai dari segi kertas yang digunakan yaitu kertas HVS A4, tinta berwarna hitam, adanya AC 24 jam, adanya APAR (Alat Pemadam Api Ringan) dan tidak adanya kamper atau kapur barus. Hasil penelitian lakukan dalam ruang penyimpanan ialah jumlah rak yang digunakan untuk menampung semua rekam medis tidak memadai. Sering terlihat semua rekam medis yang berada didasar lantai akibat tidak cukup rak penyimpanan untuk menyimpan semua rekam medis. Penyusunan rekam medis belum tersusun rapi dan tidak diletakkan dirak penyimpanan rekam medis, hal ini menyebabkan kerusakan rekam medis. Dalam menjaga keamanan rekam medis dari aspek fisik di ruang filling RSUD Petala Bumi 
yaitu dengan cara memperhatikan map rekam medis, jika ada yang rusak, map yang rusak tersebut diganti dengan yang baru.

Aspek fisik adalah kerusakan dokumen seperti kualitas kertas dan tinta yang disebabkan oleh sinar matahari, hujan, banjir, panas dan kelembaban. Bagian fisik formulir terdiri dari bahan, bentuk, ukuran, warna, dan kemasan. Berat bahan kertas harus standar untuk formulir, kertas yang digunakan sebaiknya yang tidak mudah robek dan warnanya cerah untuk berkas rekam medis terdiri dari sampul, formulir dan pembatas formulir. Tentunya sampul menggunakan bahan yang tebal, kemudian ketebalan nomor dua adalah pembatas formulir, kemudian formulir. Bentuk umum format formulir adalah segi empat. Ukuran kertas standar formulir adalah A4. Warna umum yang digunakan untuk formulir yaitu warna putih. Untuk sampul dan pembatas formulir menggunakan warna cerah. Penggunaan tinta pada tulisan dalam formulir juga perlu diperhatikan untuk kejelasan. Warna pada tinta yang digunakan pada sebagian tulisan juga dapat digunakan sebagai penegasan kalimat tertentu, tinta standar warna hitam (Huffman, 1994).

Ruang penyimpanan jangan terlalu lembab, supaya tidak terlalu lembab dapat dipasang AC yang hidup 24 jam untuk mengatur kelembapan temperatur udara serta untuk mengurangi banyaknya debu. Pemasangan harus konstan (tetap), sehingga keadaan udara yang berubah-ubah akan merusakkan kertas, apabila pergantian udara tersebut terjadi secara mendadak. Apabila suhu kurang dari normal, maka dalam waktu singkat arsip-arsip akan rusak (Wijiastuti, 2014).

Menurut teori folder atau map adalah map-map atau lipatan karton atau bahan lainnya yang memakai kawat penjepit atau tidak. Fungsinya digunakan untuk menyimpanan arsip-arsip atau dokumen rekam medis. Selain itu folder atau map dapat bermanfaat antara lain untuk:

a. Memelihara keutuhan susunan lembar rekam medis.

b. Meminimalisir terjadinya sobek pada formulir/lembar rekam medis.

c. Melindungi berkas rekam medis (DepKes RI, 2006)

Penelitian ini sejalan dengan penelitian Muhammad Husin Azam tahun (2015) dengan judul penelitian aspek keamanan isi dan fisik dokumen rekam medis ditinjau hukum kesehatan di RSUD Kartini Jepara dimana penelitian sama-sama menemukan aspek keamanan fisik dokumen rekam medis pada ruang penyimpanan. Hal ini belum sesuai dengan teori karena dalam aspek fisik keamanan dokumen rekam medis RSUD Sekadau kerusakan dokumen seperti kualitas kertas dan tinta yang disebabkan oleh sinar matahari, hujan, banjir, panas dan kelembaban dan hasil penelitian temukan dalam ruang penyimpanan jumlah rak yang digunakan untuk menampung semua dokumen rekam medis tidak memadai.

Menurut asumsi peneliti menjaga keamanan rekam medis berdasarkan aspek fisik harus lebih diperhatikan, seperti melakukan perawatan dan penyimpanan dengan baik. 


\section{Keamanan Rekam Medis Berdasarkan Aspek Biologis}

Dari aspek biologis bahwa adanya penyemprotan setiap bulan untuk melindungi berkas rekam medis dari serangan serangga.

Usaha untuk menghindari serangan seperti rayap, kecoak, dan tikus adalah dengan mengadakan pencegahan yakni peniadaan kayu yang langsung dengan tanah, diberikan kamfer pada setiap rak untuk menghindari serangan serangga (Wijiastuti, 2014).

Di ruang filling untuk menghindari dan menjaga dokumen rekam medis dari kerusakan yang disebabkan oleh serangan hama pemakan kertas, petugas fillingtidak memberikan kamper atau kapur barus pada rak filling tetapi hanya dilakukan penyemprotan setiap bulan, sedangkan menurut teori untuk menghindari dokumen rekam medis dari serangan hama dapat digunakan kapur barus disetiap sudut rak, dan sedangkan menyemprotkan racun serangga dapat mengenai rekam medis sehingga akan merusak rekam medis itu sendiri.

Hasil penelitian ini sesuai dengan jurnal Rekam medis dan Informasi Kesehatan Vol. 3, No.1, Ovtasari, M dan Pratama, R Y (2020) Aspek biologis yang kerap merusak dokumen rekam medis antara lain yaitu jamur merupakan bukti temperatur udara yang tidak terkontrol, kegiatan jamur sangat cepat karena jamur hidup dari pada perekat yang berada pada kertas, upaya menghindarinya adalah dengan menempatkan rekam medis ditempat yang kering, terang dan ruangan yang berventilasi sempurna, kutu buku sering merusak buku, jika kertas selalu tersentuh dengan dinding yang lembab, bukan saja kertas menjadi lembab, akan menghindarinya digunakan rak yang menempel dengan dinding dipasang antara lain 6 (enam) inci dari dinding.

Menurut asumsi peneliti dalam pembersihan ruang penyimpanan rekam medis dapat dilakukan secara berkala dan menggunakan kamper atau kapur barus bisa menjadi cara efektif dalam menjaga rekam medis dari serangan jamur, kutu buku dan serangga lainnya.

\section{Keamanan Rekam Medis Berdasarkan Aspek Kimiawi}

Tidak ada kerusakan rekam medis yang diakibatkan oleh serangga, masih ada petugas membawa makanan atau minuman pada saat dekat dengan rekam medis. Usaha yang dilakukan agar terhindar dari kerusakan kimiawi yaitu dengan melihat dan memperbaiki rekam medis jika terjadi kerusakan.

Aspek Kimiawi yaitu kerusakan arsip yang lebih diakibat oleh merosotnya kualitas kandungan bahan kimia dari bahan arsip, seperti penggunaan tinta yang berkualitas tidak mungkin luntur, sedangkan penggunaan tinta yang berkualitas rendah akan merusak dan melunturi kertas bila sengaja tersentuh air atau udara yang lembab. Selain itu, makanan dan minuman juga dapat mempengaruhi kerusakan DRM, karena apabila makanan dan minuman tersebut, mengandung minyak akan menempel dan menjadi kotor, bahan kimia yang terkandung dalam makanan dan minuman tersebut juga dapat merusak kertas (Setyowati, 2013). 
Hasil penelitian ini sesuai dengan jurnal Rekam medis dan Informasi Kesehatan Vol. 3, No.1, Ovtasari, M dan Pratama, R Y (2020) Kerusakan arsip yang lebih diakibatkan oleh merosotnya kualitas kandungan bahan kimia dari bahan arsip, seperti penggunaan tinta yang berkualitas tidak mungkin luntur, sedangkan penggunaan tinta yang berkualitas rendah akan merusak dan melunturi kertas bila sengaja tersentuh air atau udara yang lembab dan hasil penelitian berlangsung petugas rekam medis masih membawa makanan dan minuman pada ruang filling.

Menurut asumsi peneliti dalam menjaga keamanan rekam medis dari aspek kimiawi sangat penting dan adanya peraturan yang di tempel bisa menjadi cara efektif agar petugas menjadi lebih berhati-hati lagi.

\section{Kerahasiaan Rekam Medis}

Sudah ada peraturan bahwa selain petugas dilarang masuk, tetapi masih ada petugas lain yang melanggar. Dalam menjaga kerahasiaan isi rekam medis di RSUD Petala Bumi sudah ada peraturan bahwa orang yang tidak berkepentingan dilarang membawa dan melihat rekam medis, tetapi belum ada peraturan yang ditempelkan yang menyatakan bahwa rekam medis bersifat rahasia. Berdasarkan hasil wawancara di ruang filling upaya yang dilakukan untuk menjaga kerahasiaan rekam medis dari kehilangan yaitu adanya buku peminjaman dan kelengkapan diteliti kembali supaya ketika pencarian mudah dicari kembali tetapi masih banyak rekam medis yang diletakan dikotak tanpa menggunakan tracer. Dalam akses masuk diruang filling belum dibatasi karena selain petugas rekam medis masih dapat mengakses ruang filling seperti perawat yang diperbolehkan masuk keruangan filling, padahal dipintu masuk ruang penyimpanan rekam medis sudah ada peringatan "selain petugas dilarang masuk" tetapi peringatan tersebut masih kurang diperhatikan.Dari hasil penelitian tentang upaya untuk menjaga kerahasiaan rekam medis belum sesuai dengan teori.

Rekam medis bersifat rahasia, artinya tidak semua orang bisa membaca dan mengetahuinya. Dalam pasal 10 ayat 1 Permenkes 269/Menkes/III/2008 mengatakan bahwa informasi tentang identitas, diagnosis, riwayat penyakit, riwayat pemeriksaan dan riwayat pengobatan pasien harus dijaga kerahasiaannya oleh dokter, dokter gigi, tenaga kesehatan tertentu, petugas pengelola dan pimpinan sarana pelayanan kesehatan.

Informasi tentang identitas, diagnosis, riwayat penyakit, riwayat pemeriksaan dan riwayat pengobatan dapat dibuka dalam hal:

a. Untuk kepentingan kesehatan pasien.

b. Memenuhi permintaan aparatur penegak hukum dalam rangka penegakan hukum atas perintah pengadilan.

c. Permintaan dan/atau persetujuan pasien sendiri.

d. Permintaan institusi/lembaga berdasarkan ketentuan perundang-undangan.

e. Untuk kepentingan penelitian, pendidikan, dan audit medis sepanjang tidak menyebutkan identitas pasien. 
Tanpa adanya izin tertulis dari pasien, dokter/dokter gigi tidak boleh memberikan penjelasan tentang rekam medis kepada publik. Setiap dokter wajib merahasiakan segala sesuatu yang diketahuinya tentang seorang pasien, bahkan juga setelah seorang pasienitu telah meninggal dunia.

Bab IV butir 2 Keputusan DIRJEN Pelayanan Medik Nomor : 78/Yanmed/RS.UM.DIK./YMU/I/91 tentang petunjuk pelaksanaan penyelenggaraan rekam medik/Medical Record di rumah sakit, yang berbunyi : "Isi rekam medis adalah milik pasien yang wajib dijaga kerahasiaannya". Untuk melindungi kerahasiaannya tersebut, maka dibuat ketentuan sebagai berikut:

a. Petugas rekam medis yang diijinkan masuk penyimpanan berkas rekam medis

b. Dilarang mengutip sebagian atau seluruh isi rekam medis untuk badan-badan atau perorangan, kecuali yang telah ditentukan oleh peraturan perundang-undangan yang berlaku.

c. Selama penderita dirawat, rekam medis menjadi tanggung jawab perawat ruangan dan menjaga kerahasiaannya (Sunny, 2008).

Menurut (Dea Ayu Dindasari, 2019) untuk menjaga kerahasiaan rekam medis pasien, diperlukan ruang penyimpanan rekam medis yang memenuhi ketentuan dalam menjaga keamanan dan kerahasiaan.Ruang rekam medis dapat dikatakan baik apabila ruangan tersebut menjamin keamanan dan terhindar dari ancaman kehilangan, kelalaian, bencana, dan segala sesuatu yang dapat membahayakan rekam medis tersebut. Dalam penelitian Dea Ayu Dindasari, (2019) di RS Setia Mitra pada ruang penyimpanan rekam medis, ditemukan beberapa masalah yang berkaitan dengan keamanan dan kerahasiaan rekam medis. Ada 2 (dua) ruang penyimpanan rekam medis yang terpisah, keadaan ini dapat mengakibatkan sulitnya pengawasan.Ruang penyimpanan rekam medis tidak dikunci sehingga petugas dari bagian lain dapat masuk ke ruang penyimpanan rekam medis.Selain itu ditemukan rekam medis yang rusak seperti robek dan terlipat.Hal ini disebabkan rak penyimpanan rekam medis sudah sangat padat.

Hasil penelitian ini sesuai dengan jurnal Rekam medis dan Informasi Kesehatan Vol. 2, No.1, Wicahyanti, E T, dkk., (2020) sebaiknya untuk keamanan ruang peyimpanan rekam medis dibatasi oleh hak akses seperti fingerprintyang menggunakan karakteristik sidik jari dari manusia untuk autentikasi seperti sistem verifikasi dan identifikasi, sehingga tidak semua orang dapat keluar masuk ruang penyimpanan rekam medis

Menurut asumsi peneliti menjaga kerahasian isi rekam medis harus lebih diperhatikan lagi agar tetap terjaga kerahasiaan isi rekam medis tersebut.

\section{Kuantitas dan Kualitas Sumber Daya Manusia}

Petugas rekam medis di ruang filling masih kurang. Berdasarkan kualitasnya dalam menjaga sudah cukup bagus walaupun tidak semuanya berlatar belakang rekam medis. 
Tujuan Utama dari manajemen sumber daya manusia adalah untuk meningkatkan kontribusi sumber daya manusia (karyawan) terhadap organisasi dalam rangka mencapai produktivitas organisasi yang bersangkutan. Hal ini dapat dipahami bahwa semua kegiatan organisasi dalam mencapai misi dan tujuannya adalah sangat tergantung kepada manusia yang mengelola organisasi itu. Oleh sebab itu sumber daya manusia (karyawan) tersebut harus dikelola sedemikian rupa sehingga berdaya guna dan berhasil guna dalam mencapai misi dan tujuan organisasi (Notoatmodjo, S. 2015).

Hasil penelitian ini sesuai dengan jurnal Rekam Medis dan Informasi Kesehatan Vol. 3, No 1, Suryanto, H (2020) SDM merupakan komponen penting dan vital dalam operasional sebuah organisasi. Pelayanan kesehatan yang bermutu tidak terlepas dari penyelenggaraan rekam medis.Agar berjalan dengan baik, maka dibutuhkan sumber daya rekam medis yang cukup.

Berdasarkan asumsi peneliti bahwa sumber daya manusia sangat penting dalam menentukan keberhasilan pembangunan terutama bagi instalasi rekam medis di RSUD Petala Bumi yang masih kurang dalam kualitas sumber daya manusianya dan perlu meningkatkan pengembangan dan pelatihan sumber daya manusia, adanya penambahan tenaga rekam medis di ruang filling minimal berlatar belakang DIII rekam medis.

\section{KetersediaanStandart Operasional Procedure (SOP)}

Sudah memiliki Standar Operasional Procedure (SOP) sesuai dengan Departemen Kesehatan Republik Indonesia.

SOP pada dasarnya adalah pedoman yang berisi prosedur-prosedur operasional standar yang ada di dalam suatu organisasi yang digunakan untuk memastikan bahwa setiap keputusan, langkah, atau tindakan, dan penggunaan fasilitas pemrosesan yang dilaksanakan oleh orang-orang di dalam suatu organisasi, telah berjalan secara efektif, konsisten, standar dan sistematis (Tambunan, 2013).

Hasil penelitian ini sesuai dengan jurnal Rekam Medis dan Informasi Kesehatan Vol.2 No.1, Ayuningrum, T A (2020), Pelaksanaan pemeliharaan dokumen rekam medis membutuhkan adanya SPO untuk menunjang pemeliharaan rekam medis yang sistematis. Hal tersebut dapat mengurangi terjadinya simpang siur pekerjaan, sehingga pelaksanaan pemeliharaan dokumen rekam medis menjadi lebih teratur dan dilaksanakan secara optimal.

Berdasarkan asumsi peneliti bahwa petugas rekam medis harus menjalankan SOP yang ada karna SOP merupakan suatu aturan yang sangat penting dan tidak menjamin kegiatan tersebut berjalan optimal jika tidak di tunjang dengan adanya pedoman atau aturan, dan untuk kedepan sebaiknya ditingkatkan lagi karena setiap pekerjaan harus dijalankan sesuai dengan prosedur yang ada demi meningkatkan mutu pelayanan.

\section{Ketersediaan Sarana dan Prasarana}

Luas ruangan penyimpanan rekam medis belum memadai karena ruangannya yang kecil, lemari penyimpanannya juga masih kurang dan masih banyak rekam medis yang tidak diletakkan di lemari penyimpanan. Berkaitan dengan tata kelola ruang rekam medis dan 
ruang penyimpanan rekam medis, terdapat beberapa persoalan antara lain ruang kerja petugas masih menjadi satu dengan ruang penyimpanan rekam medis.

Pimpinan rumah sakit bertanggung jawab menyediakan sarana dan fasilitas untuk kegiatan/unit bagian rekam medis yang meliputi ruangan kegiatan, rak file, komputer, peralatan penunjang kegiatan rekam medis. Dengan demikian petugas rekam medis dapat bekerja dengan efektif dan efisien. Seluruh kegiatan yang menyangkut uraian pekerjaan rekam medis di instansi pelayanan kesehatan masing-masing (Depkes RI, 2006).

Hasil penelitian ini sesuai dengan jurnal Kesehatan Vokasional Vol. 5, No. 3, Pamboaji, A, G (2020). Aspek lain yang juga perlu mendapat perhatian guna meningkatkan efisiensi dan efektivitas pelayanan dalam pengelolaan sumber daya rekam medis adalah sarana dan prasarana yang memadai salahnya yaitu berkaitan dengan tata letak ruang kerja. Ruang kerja dengan tata letak yang baik dapat meningkatkan produktivitas kerja dan mampu memberikan kenyamanan secara fisik maupun sosial psikologis, sehingga mutu pelayanan terhadap pasien pun akan meningkat.

Berdasarkan asumsi peneliti dari hasil penelitian untuk sarana dan prasarana diruang filling ada yang belum mencukupi karena ruangan penyimpanan rekam medis yang kecil dan belum memadai. Diharapkan kepada pihak atasan rumah sakit perlu memperbesar ruangan filling rekam medis dan rak penyimpanan dibuat seperti Roll O'Pack, menggunakan traceragar lebih mudah untuk mencari status pasien. Penataan ruang kerja di unit kerja rekam medis mempengaruhi kegiatan pelayanan, sehingga tata ruang kerja di unit kerja rekam medis perlu diperhatikan agar pelayanan yang diberikan berjalan lancar dan sesuai dengan alur kerja rekam medis.

\section{Kesimpulan}

Berdasarkan hasil penelitian dan pembahasan yang penulis uraikan tentang Keamanan dan Kerahasiaan Rekam Medis di Ruang Filling Rumah Sakit Umum Daerah Petala Bumi Tahun 2021. Keamanan rekam medis pada ruang filling mulai dari aspek fisik, aspek biologis dan aspek kimia belum baik karna jumlah rak yang ada untuk menampung semua rekam medis belum memadai dan kekurangan rak penyimpanan.Dalam kerahasiaan isi rekam medis di peroleh informasi bahwadari aspek kerahasiaan sudah ada ketentuan peminjaman berkas rekam medis dan dalam upaya menjaga isi rekam medis agar terhindar dari pencurian dijelaskan bahwa tindakan pencurian tersebut akan dituntut. Kuantitas petugas yang ada di rekam medis khususnya di ruang filling masih kurang.Berdasarkan kualitasnya sudah cukup bagus walaupun tidak semuanya berlatar belakang rekam medis.Sudah memiliki Standar Operasional Procedure (SOP) sesuai dengan Departemen Kesehatan Republik Indonesia.Untuk Sarana dan prasarana seperti luas ruangan penyimpanan berkas rekam medis belum memadai karena ruangannya yang kecil, lemari penyimpanan yang masih kurang dan masih banyak rekam medis yang tidak diletakkan di rak penyimpanan. Didapat 
informasi yang berkaitan dengan tata kelola ruang rekam medis dan ruang penyimpanan berkas rekam medis, terdapat beberapa persoalan antara lain ruang kerja petugas masih menjadi satu dengan ruang penyimpanan rekam medis.

\section{Saran}

1. Dalam menjaga keamanan rekam medis berdasarkan aspek fisik sebaiknya harus lebih diperhatikan lagi seperti tidak meletakkan rekam medis di sembarang tempat, menggunakan tracer sebagai pengganti rekam medis di rak filling yang dapat digunakan untuk menelusuri keberadaan rekam medis dan juga menghindarirekam medis yang terlipat-lipat serta menyusun rapi rekam medis.

2. Dalam menjaga rekam medis dari serangan serangga seharusnya petugas tidak hanya melakukan penyemprotan yang dilakukan setiap satu bulan sekali karena jika cairan yang disemprot mengenai rekam medis dapat menyebabkan kerusakan rekam medis tersebut seharusnya petugas bisa meletakkan kamfer disetiap rak penyimpanan rekam medis.

3. Dalam menjaga keamanan rekam medis dari aspek kimiawi petugas dapat membuat peraturan seperti dilarang membawa makanan didekat rekam medis agar petugas menjadi lebih berhati-hati.

4. Dalam menjaga kerahasiaan isi rekam medis sebaiknyadibuat peraturan yang menyatakan rekam medis bersifat rahasia dan menyatakan larangan bahwa rekam medis tidak boleh difoto atau dilihat agarisi dari rekam medis milik pasien bisa terjaga dengan baik.

5. Untuk Sumber Daya Manusia (SDM) Kepala Instalasi Rekam Medis dapat merekrut tenaga kerja rekam medis sesuai dengan jurusannya, sehingga menghasilkan sumber daya manusia yang berkualitas dan mengikuti pendidikan dan pelatihan diluar rumah sakit bagi pegawai lama untuk memperbaiki kemampuan dalam melaksanakan perkerjaan dan meningkatkan kinerja khusus penyimpanan dan dalam menjaga kerahasiaan isi rekam medis.

6. Untuk SOP kedepan sebaiknya ditingkatkan lagi karena setiap pekerjaan harus dijalankan sesuai dengan prosedur yang ada demi meningkatkan mutu pelayanan.

7. Untuk meningkatkan pelayanan rekam medis, maka perlu dilakukan penataan ulang ruangan, baik dari sisi luas ruangan dan tata letaknya serta penambahan jumlah rak penyimpanan dokumen, juga menyusuaian rak antara masing-masing rak dokumen. Diharapkan kepada pihak atasan rumah sakit perlu memperbesar ruangan filling rekam medis, menambah rak penyimpanan, rak penyimpanan dibuat seperti Roll O'Pack, menggunakan traceragar lebih mudah untuk mencari status pasien. 
Daftar Pustaka

Ayu, Dindasari Dea. (2019). Tinjauan Aspek keamanan dan Kerahasiaan Rekam Medis di Rumah Sakit Setia Mitra, Jakarta Selatan. (http://akademiperekammedis.ac.id/jurnal/index.php/medicordhif/article/view/49, diakses 4 Desember 2020)

Ayuningrum, T, A, dkk., (2020). Tinjauan Pelaksanaan Pemeliharaan Dokumen Rekam Medis di Ruang Filling RSUP Dr. Sardjito. (https://publikasi.polije.ac.id/index.php/jremi/article/view/1983, diakses tanggal 25 Maret 2021)

Azam, M, H (2015). Aspek Keamanan Isi dan Fisik Dokumen Rekam Medis Ditinjau Hukum Kesehatan $d i$ RSUD

Kartini Jepara.(http://eprints.dinus.ac.id/17400/1/jurnal 16055.pdf, diakses tanggal 25 Maret 2021)

DepKes, RI, (2006). Pedoman Penyelenggaraan dan Prosedur Rekam Medis di Indonesia Revisi II, Direktorat Jendral Bina Pelayanan Medik, Jakarta.

Herlambang, S, (2016). Manajemen Pelayanan Kesehatan Rumah Sakit, Yogyakarta:Gosyen Publishing.

Khoirul, S.M. (2019). Tinjauan Keamanan dan Kerahasiaan Dokumen Rekam Medis Pada Ruang Filling di RSUD Gunung Tua Kabupaten Padang Lawas Utara (Paluta). Karya Tulis IImiah tidak diterbitkan.Program Studi DIII RMIK, Pekanbaru.

Kemenkes, RI, (2008). Manajemen Unit Kerja II Perencanaan SDM Unit Kerja RMIK.(https://bppsdmk.kemkes.go.id/pusdiksdmk/wpcontent/uploads/2018/09/Manaje men-Unit-Kerja-II SC.pdf, diakses 4 Desember 2020).

Moleong, L, J (2014). Metode Penelitian Kualitatif. Bandung: PT. Remaja Rosdakarya Notoadmodjo, S, (2010). Metode Penelitian kesehatan, Jakarta: Rineka Cipta (2015). Pengembangan Sumber Daya Manusia, Jakarta: Rineka Cipta

Ovtasari, M, dan Pratama, R, Y, (2020). Analisis Aspek Keamanan Dokumen Rekam Medis Pada Ruang Penyimpanan di RSUD Sekadau. (http://stikara.ac.id/jupermik/index.php/JK/article/view/50, Diakses tanggal 25 Maret 2021).

Pamboaji, A, G (2020).Analisis Pengelolaan Sumber Daya Unit Rekam Medis di Rumah Sakit Misi Lebak Guna Meningkatkan Efisiensi dan Efektivitas Pelayanan, Jakarta. (https://jurnal.ugm.ac.id/jkesvo/article/view/48870, diakses tanggal 25 Maret 2021).

Rustiyanto, E, (2009). Etika Profesi Perekam Medis dan Informasi Kesehatan, Yogyakarta: Graha IImu.

-(2012). Etika Profesi Perekam Medis dan Informasi Kesehatan, Yogyakarta: Graha Ilmu.

Sugiyono, (2017).Metodologi Penelitian Kualitatif,Kuantitatif, Dan R\&D. Bandung: Alfabeta. 
Suryanto, H (2020). Analisis Beban Kerja dan Kebutuhan Sumber Daya Manusia Petugas Rekam Medis Puskesmas Kediri. (http://ejournal.poltekkessmg.ac.id/ojs/index.php/RMIK/article/view/5514,__Diakses tanggal 25 Maret 2021).

Tambunan, R, (2013). Pedoman Penyusunan Standar Operasional Procedures (SOP), Jakarta: Maiestas Publishing.

UU RI No. 269 Tahun 2008 BAB 1 Pasal 1. Rekam Medis. (http://pelayanan.jakarta.go.id/download/regulasi/peraturan-meneteri-kesehatannomor-269-tentang-rekam-medis.pdf, diakses 30 November 2020).

Wicahyanti, E T, dkk., (2020). Analisis Kerahasiaan Rekam Medis Berdasarkan Hak Akses Ruang Filling Rawat Jalan di RSUD Dr. Saiful Anwar, Malang. (https://publikasi.polije.ac.id/index.php/i-remi/article/view/2073, diakses tanggal 25 Maret 2021). 